\title{
SciDoc
}

Infer, Interpret \& Inspire Science

International Journal of Dentistry and Oral Science (IJDOS)

ISSN: 2377-8075

\section{Transmedia Storytelling In Public Awareness - Impact On Present Crisis}

\author{
Research Article
}

Venkatesh $^{1 *}$, Surya ${ }^{2}$, Keerthi shashank ${ }^{3}$, Gayatri Devi ${ }^{4}$, Subhashree $^{5}$

${ }^{1}$ Department of prosthodontics Saveetha Dental College and Hospital Saveetha institute of medical and technical sciences Saveetha University, Chennai, India.

${ }^{2}$ Saveetha Dental College and Hospital, Saveetha institute of medical and technical sciences (SIMATS) Saveetha University, Chennai, India.

${ }^{3}$ Reader Department of prosthodontics Saveetha Dental College and Hospital Saveetha institute of medical and technical sciences Saveetha University, Chennai, India.

${ }^{4}$ Assistant professor Saveetha Dental College and Hospital, Saveetha institute of medical and technical sciences. Saveetha University, Chennai, India.

${ }^{5}$ Assistant Professor, Department of Prosthodontics, Saveetha Dental College and Hospitals, Saveetha Institute of Medical and Technical Sciences,

Saveetha University, Chennai.

\section{Abstract}

Transmedia storytelling is the technique of telling a single story (or) story experience across multiple platforms and formats using current digital technologies. One good example for transmedia storytelling is "DC Comics". Transmedia storytelling involves creating content that engages an audience using various techniques to permeate their daily lives. The aim of the study is to create awareness about the transmedia storytelling and to find how transmedia storytelling has an impact on the present crisis. A detailed study was done by referring several articles about transmedia storytelling in public awareness. All the articles are taken from Scopus and Pubmed databases. Articles selection includes recent study on transmedia storytelling and excludes articles with only transmedia storytelling. Scoring was done for all the 25 articles. Here by we conclude that transmedia storytelling has developed in recent times and it has many uses in public awareness in the present situation. It also helps in increasing creativity and abilities of students. Now-a-days transmedia storytelling has become a part of every individual's life.

Keywords: Digital Technologies; Government Policies; Present Crisis; Public Awareness; Transmedia Storytelling.

\section{Introduction}

Transmedia storytelling is the technique of telling a single story (or) story experience across multiple platforms using current digital technologies. Transmedia storytelling is also called transmedia narrative (or) multiplatform storytelling [23]. The study transmedia storytelling was introduced by Henry Jenkins, author of the seminal book convergence culture. The term "Transmedia" means "Across media" [2]. One good example for transmedia storytelling is "DC Comics". Transmedia storytelling involves creating content that engages an audience using various techniques to permeate their daily lives [6]. Transmedia storytelling is a narrative structure that breaks through both language and media. Some effective strategies in transmedia include a fresh perspective on the original content across a new form of media [11]. A transmedia storytelling is how well a story is comprehended across media. An effective strategy of transmedia storytelling does not take a passive approach, instead engages with popular culture making a story of its own and providing new content [18]. The aim of the study is to create awareness about transmedia storytelling and to find how transmedia storytelling has an impact on the present crisis.

\section{Materials and Methods}

Study setting was made by a scoping review. Number of articles taken 25. Search engines used are "google scholar", "Pubmed"

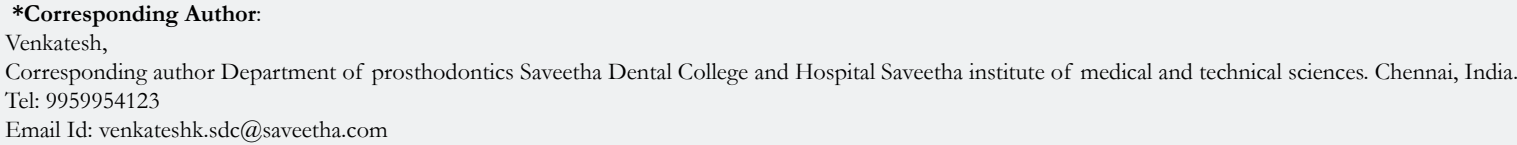

Citation: Venkatesh, Surya, Keerthi shashank, Gayatri Devi, Subhashree. Transmedia Storytelling In Public Awareness - Impact On Present Crisis. Int J Dentistry Oral Sci. 2021;08(01): 1484-1486. doi: http://dx.doi.org/10.19070/2377-8075-21000296

Copyright: Venkatesh ${ }^{2021}$. This is an open-access article distributed under the terms of the Creative Commons Attribution License, which permits unrestricted use, distribution and reproduction in any medium, provided the original author and source are credited. 
and "Medline". Search terms used are transmedia storytelling in public awareness. Five steps involved in selecting an article. They are identification of clear subject, identification of relevant articles, selection, data extraction and charting, analysis and report. The articles selected based on recent, similar and relevant publications. Articles selection includes recent study on transmedia storytelling and excludes articles with only transmedia storytelling. Scoring was done for all the 25 articles.

\section{History Of Transmedia Storytelling}

Henry Jenkins was the first person to introduce the concept transmedia storytelling [19]. By 1970 and 1980, pioneering artists of telematic art made experiments of collective narrative, mixing the ancestors of today's network and produced both visions and critical theories of what became transmedia [9]. With the advent of mainstream internet usage in the 1990's, numerous creators began to explore ways to tell stories and entertain audiences using new platforms [21]. Many examples took the form of what was to become known as alternate reality games (ARG), which took place in real time with a mass audience [17]. The term ARG was coined in 2001 to describe the beast, a marketing company for the film A.I: Artificial intelligences. Some examples of ARG are star wars, star sterk, the matrix, the beast, on line, disney, marvels and DC comics [8].

\section{Current Status Of Transmedia Storytelling}

Both traditional and dedicated transmedia entertainment studies have fully integrated and embraced transmedia storytelling techniques into entertainment culture [24]. Some examples of transmedia storytelling are slide, skin, halo, justice for hire, my music, clockwork watch, endgame: proving ground, 24, the hunger games and Pokemon [18]. In present, transmedia storytelling has developed a lot and it is ruling the mass media. Many comics, books and even movies based on transmedia storytelling have been released in recent times [27].

\section{Educational Uses Of Transmedia Storytelling}

Transmedia narrating imitates a solid constructivist academic instrument for instructive uses. Schools have been gradually adjusting to this new culture which moves the spotlight of proficiency from being one individual articulation to one network [14]. Utilizing transmedia narrating as an educational device, where in understudies associate with stage, for example, twitter, facebook, instagram (or) tumblr grants understudies perspectives, encounters, and assets to build up a mutual aggregate knowledge that is alluring, connecting with, vivid, grabbing the millennial eye, guaranteeing students a stake in understanding [15]. Transmedia storytelling offers the students to think critically, identify with the materials and knowledge, offering a valuable framework for the constructivist educational pedagogy that supports students learning. It also helps in increasing creative knowledge in students [7]. Transmedia storytelling allows for the interpretation of the story from the individuals, perspective, making way for personalized meaning making. Transmedia storytelling is also used in companies like microsoft and kimberly-clark to train employees and managers $[12,20]$. However it is not used in lower education levels [16]. Transmedia storytelling is apparent in comics, films, print media, radio and now social media also.

\section{Impact On Government Policy}

The two good examples of transmedia storytelling in impact on government policies are the case of fish fight and the housing case in British [28]. In the case of fish fight, for centuries, discarded fish has been an inevitable consequence of the fish industry, which is justified by numerous economic, political, biological and technological reasons [10]. European fishers look for ways to reduce expenses and landing the whole catch would impose extra cost on the economical sector [25]. They selected one fish type and started catching it, which results in marking the species endangered [30]. People of Europe fish fight grass root campaign, they started fighting against the fishing companies through transmedia storytelling [26]. They created awareness about the fish species among people. Later the government set up a law for this problem which was named as Hugh's Fish Fight, 2010 [13]. In the case of British, over 2 million people are in need of home and food, and about 1 million houses were not used due to its poor conditions [22]. This happened in the year 2011 in the UK. A TV channel "Channel 4" created the project together with architect George Clarke, who started a personal crusade against British housing problem after realizing the fact [4]. People got knowledge about their current situation through that program and fought against the government [1]. Government has reconstructed the houses and gave them to the people [3]. The transmedia storytelling TV program "Great British property scandal storyworld : Phil's empty Homes giveaway and Kevin's grand design” helps the people in their hard struggles [29]. Due to this program over 1,18,200 petitions were signed, 10,000 empty houses were reported, 17 million Euro were allotted for houses and George Clarke was appointed as Independent empty home advisor to the government [5].

\section{Conclusion}

Here by we conclude that transmedia storytelling has developed in recent times and it has many uses in public awareness in the present situation. Through transmedia storytelling people are getting known knowledge about the present situation. It also helps in increasing creativity and abilities of students.Now-a-days transmedia storytelling has become a part of every individual's life.

\section{Acknowledgements}

The author would like to acknowledge the help and support rendered by the Department of Oral Pathology and Information Technology of Saveetha Dental College and Hospitals and the management for their constant assistance with the research.

\section{References}

[1]. Ajay R, Suma K, Ali SA, Kumar Sivakumar JS, Rakshagan V, Devaki V, et al. Effect of Surface Modifications on the Retention of Cement-retained Implant Crowns under Fatigue Loads: An In vitro Study. J Pharm Bioallied Sci. 2017 Nov;9(Suppl 1):S154-S160.Pubmed PMID: 29284956.

[2]. Jain AR, Nallaswamy D, Ariga P, Ganapathy DM. Determination of correlation of width of maxillary anterior teeth using extraoral and intraoral factors in Indian population: A systematic review. World J Dent. 2018 Jan;9:68-75.

[3]. Ashok V, Nallaswamy D, Benazir Begum S, Nesappan T. Lip Bumper Prosthesis for an Acromegaly Patient: A Clinical Report. J Indian Prosthodont Soc. 2014 Dec;14(Suppl 1):279-82.Pubmed PMID: 26199531.

[4]. Ashok V, Suvitha S. Awareness of all ceramic restoration in rural population. 
Res J Pharm Technol. 2016 Oct 28;9(10):1691-3.

[5]. Basha FY, Ganapathy D, Venugopalan S. Oral hygiene status among pregnant women. Res J Pharm Technol. 2018 Jul 31;11(7):3099-102.

[6]. Bourdaa, M. 'Transmedia Storytelling', The Routledge Companion to Transmedia Studies.2018; 133-140. doi: 10.4324/9781351054904-15.

[7]. Coen E. The storytelling arms race: origin of human intelligence and the scientific mind. Heredity (Edinb). 2019 Jul;123(1):67-78.Pubmed PMID: 31189903.

[8]. Duraisamy R, Krishnan CS, Ramasubramanian H, Sampathkumar J, Mariappan S, Navarasampatti Sivaprakasam A. Compatibility of Nonoriginal Abutments With Implants: Evaluation of Microgap at the Implant-Abutment Interface, With Original and Nonoriginal Abutments. Implant Dent. 2019 Jun;28(3):289-295.Pubmed PMID: 31124826.

[9]. Finkel E, Malakoff D, Balter M, Lawler A. Fish fight. Science. $2002 \mathrm{Mar}$ $1 ; 295(5560): 1619$.

[10]. Freeman, M.'Historicising Transmedia Storytelling'. 2016. doi: $10.4324 / 9781315439525$.

[11]. Gambarato RR, Medvedev SA. Transmedia storytelling impact on government policy change. In Politics, protest, and empowerment in digital spaces 2017 (pp. 31-51). IGI Global.

[12]. Ganapathy D, Sathyamoorthy A, Ranganathan H, Murthykumar K. Effect of Resin Bonded Luting Agents Influencing Marginal Discrepancy in All Ceramic Complete Veneer Crowns. J Clin Diagn Res. 2016 Dec;10(12):ZC67ZC70.Pubmed PMID: 28209008.

[13]. Ganapathy DM, Kannan A, Venugopalan S. Effect of coated surfaces influencing screw loosening in implants: A systematic review and meta-analysis. World J. Dent. 2017 Nov;8(6):496-502.

[14]. Heilemann MV, Soderlund PD, Kehoe P, Brecht ML. A Transmedia Storytelling Intervention With Interactive Elements to Benefit Latinas' Mental Health: Feasibility, Acceptability, and Efficacy. JMIR Ment Health. 2017 Oct 19;4(4):e47.Pubmed PMID: 29051135.

[15]. Heilemann MV, Martinez A, Soderlund PD. A Mental Health Storytelling Intervention Using Transmedia to Engage Latinas: Grounded Theory Analysis of Participants' Perceptions of the Story's Main Character. J Med Internet Res. 2018 May 2;20(5):e10028.Pubmed PMID: 29720357.

[16]. Hogg, JL. 'Transmedia Storytelling in Education, Training, and Behavior Change', PsycEXTRA Dataset.2012. doi: 10.1037/e635602012-001.

[17]. Hovious A, Shinas VH, Harper I. The Compelling Nature of Transme- dia Storytelling: Empowering Twenty First-Century Readers and Writers Through Multimodality. Technol. Knowl. Learn. 2020 Mar 11:1-5.

[18]. Javanshir R, Carroll B, Millard D. Structural patterns for transmedia storytelling. PLoS One. 2020 Jan 31;15(1):e0225910.Pubmed PMID: 32004322 .

[19]. Jyothi S, Robin PK, Ganapathy D. Periodontal health status of three different groups wearing temporary partial denture. Res J Pharm Technol. 2017 Dec 1;10(12):4339-42.

[20]. Kannan A, Venugopalan S. A systematic review on the effect of use of impregnated retraction cords on gingiva. Res J Pharm Technol. 2018 May 30;11(5):2121-6.

[21]. Laycock, J. 'Legend-Tripping Online: Supernatural Folklore and the Search For Ong's Hat. By Michael Kinsella. Jackson, MS: University Press of Mississippi.2011. Pp. xii 211. \$55.00', Religious Studies Review.2014; 136-137. doi: $10.1111 /$ rsr. 12144

[22]. McCrone G, Stephens M. Housing policy in Britain and Europe. Routledge; 2017 Sep 19: 139-178.

[23]. Miller CH. 'Using a Transmedia Approach', Digital Storytelling, 2008; 149 163. doi: 10.1016/b978-0-240-80959-5.50016-4.

[24]. Paton A, Kotzee B. The fundamental role of storytelling and practical wisdom in facilitating the ethics education of junior doctors. Health (London). 2019 Nov 18:1363459319889102.Pubmed PMID: 31739676.

[25]. Ranganathan H, Ganapathy DM, Jain AR. Cervical and Incisal Marginal Discrepancy in Ceramic Laminate Veneering Materials: A SEM Analysis. Contemp Clin Dent. 2017 Apr-Jun;8(2):272-278.Pubmed PMID: 28839415.

[26]. Secretariat C. The Failure of European Fishing Policy.2003.

[27]. Selvan SR, Ganapathy D. Efficacy of fifth generation cephalosporins against methicillin-resistant Staphylococcus aureus-A review. Res J Pharm Technol. 2016 Oct 28;9(10):1815-8.

[28]. Subasree S, Murthykumar K. Effect of aloe vera in oral health-A review. Res J Pharm Technol. 2016 May 1;9(5):609.

[29]. Venugopalan S, Ariga P, Aggarwal P, Viswanath A. Case Report: Magnetically retained silicone facial prosthesis. Niger. J. Clin. Pract. 2014 Mar 27;17(2):260-4

[30]. Vijayalakshmi B, Ganapathy D. Medical management of cellulitis. Res J Pharm Technol. 2016 Nov 28;9(11):2067-70. 